ROCZNIKI TEOLOGICZNE

Tom LXVIII, zeszyt $2-2021$

DOI: https://doi.org/10.18290/rt21682-4

MARIAN KOWALCZYK S.A.C.

\title{
SHARING IN THE EUCHARISTIC SACRIFICE OF CHRIST
}

\begin{abstract}
A b stract. Staying in the stream of the pastoral program of the Church in Poland, which is carried out under the slogan "Gathered at the Holy Supper," the content of the article focuses on the analysis and synthesis of the documents of the Magisterium of the Church and theological publications on the Eucharistic sacrifice. First, the article discusses the Eucharistic making present of the sacrifice of the Cross as a gift of glorified Christ, and then draws attention to the active participation of the faithful in the Eucharistic making present of Calvary. The context of God's mercy in the Eucharistic Sacrifice is also emphasized. The climax of the article is the interpretation of the eschatic dimension of the Eucharist, confirmed by the testimony of the life of Christians, joining in the sacrifice of Christ and in his death and resurrection, which result in the perfect joy of the saved in heaven.
\end{abstract}

Keywords: re-presenting of the only sacrifice of Christ; the Eucharist as a sacrifice of perfect worship; participation of the faithful in the Eucharistic sacrifice; the eschatic dimension of the Eucharist.

The Eucharist, the supreme gift of Christ to the Church, makes the sacrifice offered by Christ for our salvation present in a sacramental way: "The Eucharist, in fact, is the perfect 'sacrifice of praise,' the highest glorification that rises from earth to heaven, 'the source and summit of the Christian life in which (the children of God) offer the divine victim (to the Father) and themselves along with it." "1 These words express the participation of the faithful in the Eucharistic sacrifice of Christ, which St. John Paul II, in his post-synodal apostolic exhortation Ecclesia in Europa, recommended to

Prof. dr. hab. Marian KowalczYK S.A.C-Faculty of Theology, Cardinal Stefan Wyszyński University in Warsaw; address for correspondence: ul. Dewajtis 5, 01- 815 Warszawa; e-mail: mkowalczyk@sac.org.pl; ORCID: https://orcid.org/0000-0002-7006-4144

${ }^{1}$ Pope John Paul II, Catechesis at the general audience of October 11, 2000; cf. Vaticanum II, Dogmatic Constitution on the Church Lumen gentium, 11. 
Europe, addressing it as a person. It seems as if he addressed his words to all Europeans and to each individual. The Pope wrote: "Europe, as you stand at the beginning of the third millennium, 'Open the doors to Christ! Be yourself. Rediscover your origins. Relive your roots.",2

Undoubtedly, the Pope meant the return of Europeans to the Christian culture and identity, which commands us to imitate Christ present among us, especially in the Blessed Sacrament of the Eucharist, which is also the source and summit of Christian life. The Eucharist "spurs us on our journey through history and plants a seed of living hope in our daily commitment to the work before us." 3 Therefore, since the Eucharist is at the centre of all the Church's initiatives, while accepting the words of St. John Paul II, who clearly indicates that Europe is losing its identity, we must ask how exactly to implement his dramatic appeal. Zealous followers of Christ try to answer this question with their word and life.

The issue of participation in the Eucharist as a sacrifice is one of the most important elements of the cult of the Blessed Sacrament. For if the Eucharist appears as a way of returning to the sources of our faith and reaching the summit of Christian life, then the formulation of the title of this study contains an answer to the question that concerns us. Acknowledging the importance of the Church's sacraments, we must be convinced that without placing the Eucharist at the very centre of our lives, no cult of God in the Holy Trinity ${ }^{4}$ is possible, nor is there any apostolate or evangelization of the world.

In presenting the issues we are interested in, we will first pay attention to the Eucharist as the highest gift of the glorified Christ, who through the Holy Spirit, in a sacramental way, realizes the Sacrifice offered on the altar of the Cross for the world's salvation. Then, we will emphasize the necessity of our participation in the salvific Sacrifice of Christ, which culminates in the participation of all the saved in the perfect joy of heaven, that is, in the mystery of the communion of saints and eternal life in the world to come.

\footnotetext{
2 John Paul II, Post-Synodal Exhortation Ecclesia in Europa, 120.

${ }^{3}$ Ibidem, 20.

${ }^{4}$ Cf. Avery Dulles, "The Eucharist and the Mystery of the Trinity," in Rediscovering the Eucharist. Ecumenical Conversations, ed. Roch A. Kereszty (Mahwah, N.J.: Paulist Press, 2003), 226-39.
} 


\section{THE EUCHARISTIC RE-PRESENTATION OF THE SACRIFICE OF THE CROSS AS A GIFT OF THE GLORIFIED CHRIST}

For the sake of a proper understanding of the Mystery of the Eucharist, Cardinal Joseph Ratzinger / Benedict XVI emphasizes that "Jesus died exactly at the time when sacrificial lambs were killed in the temple for the feast of Passover. This moment of death indicates that He is the true Paschal Lamb; that the Passover lambs ended their role part, because the Lamb without blemish came." 5

The followers of Christ know perfectly well that the blood and water that flowed from the Saviour's open side are the Eucharist and Baptism-the source of a new community of the saved. ${ }^{6}$ They, therefore, easily accept the fact that these sacraments are related to the sacrifice of Christ on the cross. However, it must be admitted that the contemporary followers of Christ often forget about this relationship. In liturgical practice, there are distortions or arbitrary experiments which sometimes develop to such an extent that it is difficult to distinguish the Eucharistic making present of the saving Sacrifice of Christ from a banquet or feast. Rays coming from the heart of Jesus convince us that the Eucharist not only quantitatively, but also qualitatively, that is, in essence, exceeds the ordinary form of a banquet or any secular celebration. This is why Benedict XVI reminds us that "everyone should be able to experience and express the awareness that at each celebration we stand before the infinite majesty of God, who comes to us in the lowliness of the sacramental signs." 7

It is true that Jesus instituted the Eucharist during a meal consumed with the Apostles in the atmosphere of the Jewish feast of Passover. However, this does not change the fact that on Holy Thursday, during the Last Supper, Jesus gives something completely new: Himself. In this way, Jesus anticipates his cross and his resurrection, according to the words: "I lay down my life in order to take it up again. No one takes it from me, but I lay it down of my own accord. I have power to lay it down, and I have power to take it up

\footnotetext{
${ }^{5}$ Joseph Ratzinger, Eucharystia. Bóg jest blisko nas (Kraków Wydawnictwo M, 2002), 45; cf. Joseph Ratzinger, "Ostatnia Wieczerza a Eucharystia Kościoła," in Communio: Międzynarodowy Przegląd Teologiczny: Świeccy w Kościele, ed. Lucjan Balter, Kazimierz Czulak, Paweł Góralczyk, and Stanisław Stancel (Poznań-Warszawa: Pallottinum, 1987), 162-74.

${ }^{6}$ Cf. Paweł Warchoł, Krew i woda, dar miłości miłosiernej (Warszawa: Wydawnictwo Sióstr Loretanek, 2015), 82-95.

${ }^{7}$ Benedict XVI, Post-Synodal Apostolic Exhortation Sacramentum caritatis, 65.
} 
again. I have received this command from my Father" (Jn 10:17-18). ${ }^{8}$ It should be strongly emphasized that the Cenacle and the Cross at Golgotha are manifestations of the same Eucharistic Sacrifice, which are becoming a reality that is still present today, through the power of Jesus' saving deeds, through the Holy Spirit sent at Pentecost. ${ }^{9}$

The truth about the Mass as a sacrifice is clearly confirmed by the Council of Trent, thus responding to the Protestant doctrine at the time. The same question is also addressed by St. Paul VI in his Creed of June 30, 1968. He strongly believes that the Mass "is the sacrifice of Calvary rendered sacramentally present on our altars. We believe that as the bread and wine consecrated by the Lord at the Last Supper was changed into His body and His blood which were to be offered for us on the cross, likewise the bread and wine consecrated by the priest are changed into the body and blood of Christ enthroned gloriously in heaven." 10

Already at the beginning of his pontificate of St. John Paul II wrote: "The Eucharist is above all else a sacrifice. It is the sacrifice of the Redemption and also the sacrifice of the New Covenant, as we believe and as the Eastern Churches clearly profess: 'Today's sacrifice,' the Greek Church stated centuries ago, 'is like that offered once by the Only-begotten Incarnate Word; it is offered by Him (now as then), since it is one and the same sacrifice." "11

Highlighting the close relationship between the Eucharist and the sacrifice of Golgotha, in the encyclical addressing the topic of interest to us, St. John Paul II notes that the Eucharist is "a sacrifice in the strict sense, and not only in a general way, as if it were simply a matter of Christ's offering himself to the faithful as their spiritual food. The gift of his love and obedience to the point of giving his life (cf. Jn 10:17-18) is in the first place a gift to his Father [...], it is a sacrifice that the Father accepted, giving, in return for this total self-giving by his Son, who 'became obedient unto death' (Phil 2:8), his own paternal gift, that is to say the grant of new immortal life in the resurrection." $" 12$

\footnotetext{
${ }^{8}$ Cf. Benedict XVI, Catechesis of January 11, 2012. All Bible quotations are from the New Revised Standard Version (NRSV) unless stated otherwise.

${ }^{9}$ Cf. C. John Collins, "The Eucharist as Christian Sacrifice: How Patristic Authors Can Help Us Read the Bible," Westminster Theological Journal 66, no 1 (Spring 2004), 1-23.

${ }^{10}$ Paul VI, Apostolic Letter Solemni hac liturgia, 24; cf. David H. Tripp, "Protestantism and the Eucharist," in The Study of Liturgy, ed. Cheslyn Jones, Geoffrey Wainwright, Edward Yarnold, and Paul Bradshaw (London: SPCK, 1992) (revised edition), 295-309.

${ }^{11}$ John Paul II, Letter Dominicae Cenae, 9; cf. Edward Ozorowski, "Ofiara jako 'primum principium’ Eucharystii," Rocznik Teologii Katolickiej 5(2006), 9-21.

${ }^{12}$ John Paul II, Encyclical Letter Ecclesia de Eucharistia, 13.
} 
During one of the general audiences in the Year of the Great Jubilee 2000, Pope John Paul II said that "first of all the sacrifice of Christ becomes present in the Eucharist. Jesus is really present under the appearances of bread and wine, as he himself assures us: 'This is my body... this is my blood' (Mt 26: 26, 28). But the Christ present in the Eucharist is the Christ now glorified, who on Good Friday offered himself on the cross. This is what is emphasized by the words he spoke over the cup of wine: 'This is my blood of the covenant, which is poured out for many' (Mt 26:28; cf. Mk 14:24; Lk 22:20). If these words are examined in the light of their biblical import, two significant references appear. The first consists of the expression 'blood poured out' which, as the biblical language attests (cf. Gn 9:6), is synonymous with violent death. The second is found in the precise statement 'for many,' egarding those for whom this blood is poured out. The allusion here takes us back to a fundamental text for the Christian interpretation of Scripture, the fourth song of Isaiah: by his sacrifice, the Servant of the Lord 'poured out his soul to death,' and 'bore the sin of many' (Is 53:12; cf. Heb 9:28; 1 Pt 2:24)."13

Cardinal Ratzinger also spoke shockingly of the Mass as a sacrifice, stating that "the Eucharist is far more than just supper; it cost Someone death and the majesty of death becomes present. Of course, the awareness that the One conquered death through the resurrection allows us to celebrate the feast of life in the Eucharist, but without touching on this decisive aspect, the Eucharist would remain something superficial and insignificant." 14 Knowing what the death of a loved one is for us, we fully understand that it remains "an issue above all issues, and where it is excluded, there is ultimately no answer. Only where there is an answer to it can a person truly celebrate and be free. The Christian celebration of the Eucharist reaches this depth of death." 15

The same truth resounds in the joyful singing of Easter Sunday Sequence: "Death and life have contended in that combat stupendous: The Prince of life, who died, reigns immortal" and in the Mass Preface III for the Easter period: "he is the sacrificial Victim who dies no more, the Lamb, once slain, who lives for ever." St. John Paul II adds that as living and risen, Christ can make himself in the Eucharist the "bread of life" (Jn 6:35, 48), "living bread" (Jn 6:51),

${ }^{13}$ John Paul II, Catechesis at the general audience of October 11, 2000; A.M. Watts, "Sacrament and Sacrifice. Attending to Some Neglected Biblical Threads," Toronto Journal of Theology 24, no. 1 (Suppl.) (2008): 143-52. John P. Joy, "Ratzinger and Aquinas on the Dating of the Last Supper. In Defense of the Synoptic Chronology," New Blackfriars 94, no. 1051 (2013): 324-39.

${ }^{14}$ Ratzinger, Eucharystia, 47; Joy, "Ratzinger and Aquinas."

${ }^{15}$ Ratzinger, Eucharystia, 47. 
thus confirming his specific presence and continuing validity of the teaching of the Council of Trent that "the consecration of the bread and wine effects the change of the whole substance of the bread into the substance of the body of Christ our Lord, and of the whole substance of the wine into the substance of his blood. And the holy Catholic Church has fittingly and properly called this change transubstantiation." ${ }^{\prime 16}$ Thanks to the transubstantiation "the Eucharistic sacrifice is the source and the summit of the whole of the Church's worship and of the Christian life." The faithful participate more fully in this sacrament of thanksgiving, propitiation, petition, and praise, not only when they wholeheartedly offer the Sacred Victim, and in it themselves, to the Father with the priest, but also when they receive this same Victim sacramentally."17

It is appropriate to recall here the firm exhortation of John Paul II in the encyclical on the Eucharist, in which he emphatically states that "the celebration of the Eucharist, if it is to be a truly Eucharistic assembly, absolutely requires the presence of an ordained priest as its president. On the other hand, the community is by itself incapable of providing an ordained minister. This minister is a gift which the assembly receives through episcopal succession going back to the Apostles." 18

This sounded even more firmly in the Letter to Priests for Holy Thursday 2004, in which John Paul II quotes the words of a book written for the fiftieth anniversary of his priesthood: "We were born from the Eucharist. If we can truly state that the whole Church lives from the Eucharist (Ecclesia de Eucharistia vivit), as I reaffirmed in my recent Encyclical, we can say the same about the ministerial priesthood: it is born, lives, works and bears fruit «de Eucharistia» (cf. Council of Trent, Sess. XXII, canon 2: DS 1752). "There can be no Eucharist without the priesthood, just as there can be no priesthood without the Eucharist» (cf. Gift and Mystery. On the Fiftieth Anniversary of My Priestly Ordination, New York, 1996, pp. 77-78)." 19

${ }^{16}$ John Paul II, Encyclical Letter Ecclesia de Eucharistia, 14-15. The Pope recalls the decision of the 13th Session of the Council of Trent written in the fourth chapter of the Decree on the Holy Eucharist.

${ }^{17}$ Sacred Congregation of Rites, Eucharisticum Mysterium, 3e.; cf. Roch A. Kereszty, "The Eucharist of the Church and the One Self-Offering of Christ," in Rediscovering the Eucharist. Ecumenical Conversations, ed. Roch A. Kereszty (Mahwah, N.J.: Paulist Press, 2003), 240-60.

${ }^{18}$ John Paul II, Encyclical Letter Ecclesia de Eucharistia, 29.

${ }^{19}$ John Paul II, Dar i tajemnica (Kraków: Wydawnictwo św. Stanisława BM, 1996), 75; cf. Sacred Congregation of the Doctrine of the Faith, Sacerdotium Ministeriale. Letter to Bishops of the Catholic Church on Certain Questions Concerning the Minister of the Eucharist. Rome, August 6, 1983. AAS 75 (1983): 1001-9. 
Bearing in mind the above rulings, Pope Francis, in the post-synodal apostolic exhortation Querida Amazonia, recalls the words of the conciliar decree on the ministry and life of priests, repeated by St. John Paul II in the encyclical Ecclesia de Eucharistia, where we read that "no Christian community, however, is built up unless it has its basis and centre in the celebration of the most Holy Eucharist." ${ }^{20}$ The Pope also shares the opinion of the Council Decree Presbyterorum ordinis, on the service and life of priests, No. 5 and of St John Paul II from encyclical Ecclesia de Eucharistia, No. 22 and states that the priest celebrates the Eucharist in Persona Christi Capitis (in the person of Christ the Head), i.e. "the priest is a sign of that head and wellspring of grace above all when he celebrates the Eucharist, the source and summit of the entire Christian life. That is his great power, a power that can only be received in the sacrament of Holy Orders. For this reason, only the priest can say: «This is $m y$ body». There are other words too, that he alone can speak: «I absolve you from your sins»."21

\section{THE PARTICIPATION OF THE FAITHFUL IN THE EUCHARISTIC SACRIFICE OF CHRIST}

"The Eucharistic Sacrifice is intrinsically directed to the inward union of the faithful with Christ through communion; we receive the very One who offered himself for us, we receive his body which he gave up for us on the Cross and his blood which he "poured out for many for the forgiveness of sins' (Mt 26:28)."22 The quoted words of St. John Paul II undeniably show that the merits of the Cross are applied to the Eucharistic sacrifice, but not without the active participation of the faithful. Active and full participation in the Holy Mass is a necessary condition for every follower of Christ to come into live contact with his Paschal sacrifice. According to the teachings of the Church Fathers it can be said, following Pius XII, that "in a certain sense it can be said that on Calvary Christ built a font of purification and salvation which He filled with the blood He shed; but if men do not bathe in it and there wash away the stains of their iniquities, they can never be purified and saved." ${ }^{23}$

\footnotetext{
${ }^{20}$ Vaticanum II, Decree Presbyterorum ordinis, 6.

${ }^{21}$ Pope Francis, Post-Synodal Apostolic Exhortation Querida Amazonia, 88.

22 John Paul II, Encyclical Letter Ecclesia de Eucharistia, 16.

${ }^{23}$ Pope Pius XII, Encyclical Mediator Dei et hominum, Castel Gandolfo 1947, 77.
} 
Speaking about the participation of the faithful in the Eucharistic sacrifice of Christ and the Church, the innate sense of the need for sacrifice to properly honour God is emphasized. The point is that man naturally feels that the words of petitions and praises addressed to God must be confirmed by deed, by personal sacrifice. Sacrifices made to pagan gods often reached for human life, when a priest, for example, ripped out a man's living heart or when as a token of gratitude for victory over the enemy prisoners of war were murdered. Wigand Siebel sees this understanding of the necessity of sacrifices offered to idols in every religion, including the Catholic one. ${ }^{24}$ In order not to be exposed to similar accusations, Hans Urs von Balthasar proposes that the word "sacrifice" should be avoided in relation to the Eucharist and that the word "self-offering" or "handing over" could be used instead. ${ }^{25}$ It should be added, however, that speaking of the Mass as a sacrifice is obviously not forbidden, provided that the word's analogy is remembered. This analogy is clearly expressed by the definition of the Eucharistic sacrifice as sacrificium laudis, i.e. "the perfect sacrifice of worship, the supreme sacrifice of praise rising from earth to heaven, participating in this «fount and apex of the whole Christian life, they offer the Divine Victim to God, and offer themselves along with It» (Lumen gentium 11)."26

It is true that in the canon of the Mass the Church asks Christ to recognize that "this is the same sacrifice through which he wanted to reconcile us with himself", but this "recognition" falls within the framework of annihilation (immolation), that is, the one and unique sacrifice that Christ himself made on the tree of the cross, accepting this "sacrifice" voluntarily (Jn 10:18) in place of sinners, for whose salvation God "made him $\sin$ " (2 Cor 5:21) ${ }^{27}$ It should always be remembered that during the Mass we offer the victim already destroyed on Good Friday, which the Council of Trent confirms with the words: "For the victim is one and the same, the same now offering by the ministry of priests, who then offered Himself on the cross, the manner alone of offering being different. The fruits indeed of which oblation, of that bloody one to wit, are received most plentifully through this unbloody one; so

${ }^{24}$ Cf. Wigand Siebel, Freihait und Herschaftstruktur in der Kirche. Eine soziologische Studie (Berlin: Morus-Verlag, 1971), 20-52.

${ }^{25}$ Cf. Hans Urs von Balthasar, "Od Ostatniej Wieczerzy do ofiary Kościoła," trans. Teresa Sotowska, in Communio. Międzynarodowy Przeglad Teologiczny, vol. 1: Eucharystia, ed. Paweł Góralczyk, 175-88. Poznań-Warszawa: Pallottinum, 1986.

${ }^{26}$ Jan Paweł II, Komentarz do Ksiag Nowego Testamentu, Kraków 2012, p. 591.

${ }^{27}$ Cf. Ibidem, p. 182-185. 
far is this (latter) from derogating in any way from that (former oblation)." 28 One of the most important rulings of the Council of Trent includes the unequivocal statement that in every Eucharist "a true and singular sacrifice" 29 through Christ is made.

Analysing what Christ's eucharistic sacrifice is exactly about, Hans Urs von Balthasar observes that the categories of "bloody"- "unbloody" - do not accurately show the depth of this sacrifice, for it is more about the spiritual state than the purely bodily separation of "Body" and "Blood." The sacrifice of Jesus for the sins of the world was the highest self-denial for the Son of God, living in closeness and intimacy with God the Father. ${ }^{30}$ Establishing the Holy Sacrifice of the Eucharist, Jesus Christ convinces us that the idea of this Sacrifice was never based on "making sacrifices" alone, but on the Eucharistic Prayer or "canon." An analysis of the canon of the Mass makes it possible to state decisively that the novelty of the Eucharist consists, as we have already mentioned, in the presence of Christ, who died and rose for us. And the very term "offering" to name of the action during the Mass, after the Prayer of the faithful, may be associated with the need to make indescribable sacrifices for the appropriate worship of God. Here one could recall the renunciation of property by members of the first Christian community (Acts $2: 44)$, as well as point to the "donations of the faithful collected in ages for the needs of the Church and the poor", which today is reflected in the Fifth Ecclesiastical Commandment, and was, and in a sense still is, closely related to the celebration of the Eucharist as a sacrifice. It is not excluded that the so-called "Mass stipends" developed from the former material offerings that were brought to the church and practically contributed to the maintenance of the priest, who shared them with those deprived of basic goods and, therefore, starving. Finally, one could point to the money given on a tray at that moment of the Mass, intended for the maintenance of the temple or for other purposes, indicated by the shepherds of the Church. ${ }^{31}$

Well, all these elements can in no way satisfy the sacrifice of Christ. Therefore, the proper name for this moment of the Holy Mass it is not offering, but "preparing gifts." It is all about "delivery," "bringing in," "putting at one's disposal." By such wording it is emphasized that the Eucharist is a disproportionate gift of Jesus Christ himself and only then will

\footnotetext{
${ }^{28}$ The Council of Trent, Session 22, On the Sacrifice of the Mass.

${ }^{29}$ Ibidem.

${ }^{30} \mathrm{H}$. Urs von Balthasar, Od Ostatniej Wieczerzy do ofiary Kościoła, in: Eucharystia, 185.

${ }^{31} \mathrm{Ibidem}$.
} 
it retain its greatness when we make our gifts in the conviction that now, at every Holy Mass, we still offer the same Paschal Lamb, thanks to whom the victim that was once offered will never be consumed. ${ }^{32}$

However, by giving his saving sacrifice to the Church, Christ wants all God's people to actively participate in it. For He is not a Priest and a Victim for Himself, but for us, humans, and for our salvation, according to the words of the high priest's prayer: "And for their sake I consecrate myself, that they also may be consecrated in truth" (Jn 17:19, RSV). As followers of Christ, we have been included in his sacrifice of the cross, so we can say without exaggeration that by linking our personal sacrifices to his Most Holy Sacrifice we make a sacrifice to God not only on Jesus' behalf, but most importantly, he himself, the only High Priest, makes to the Father an offering on our behalf. That is why the words, "If you ask anything of the Father in my name, he will give it you" (Jn 16:23), find their most appropriate place in the sacrifice of the Mass.

This does not mean, however, that by bringing bread and wine, the fruit of the work of human hands, to the altar, and asking that these gifts become the bread of life and a spiritual drink, we are exempt from the sacrificial disposition of our spirit. On the contrary, by joining with the Sacrifice of Christ, we are to adopt the attitude of sacrifice, deny ourselves, willingly give ourselves to the works of penance and atonement for our sins. The words of Christ: "If any want to become my followers, let them deny themselves and take up their cross and follow me" (Mt 16:24) imply the need for active "co-offering" in the existential consent to Christ's only Sacrifice, up to the desire to suffer a "mystical death," following St. Paul the Apostle who cried out: "I have been crucified with Christ" (Ga 2:19-20).

Only a man so united with the Sacrifice of Christ can be fully entitled to a shocking call: "I appeal to you therefore, brothers and sisters, by the mercies of God, to present your bodies as a living sacrifice, holy and acceptable to God, which is your spiritual worship" (Rom 12:1). The Mother of Jesus holds first place in the implementation with all certainty. The co-suffering of the Mother standing under the cross of her dying Son was the pinnacle of Mary's response of faith to the saving will of God. According to John Paul II, in the experience of Golgotha, the faith of Mary underwent the greatest "kenosis" in history. ${ }^{33}$ It was there, on Golgotha that by heroic obedience

\footnotetext{
32 John Paul II, Encyclical Letter Ecclesia de Eucharistia, 12.

${ }^{33}$ John Paul II, Encyclical Redemptoris Mater, 18; cf. Teofil Siudy, "Wiara - jakby klucz do prawdy o Maryi," in Matka Odkupiciela, text and comments ed. S.C. Napiórkowski, Lublin 1993, 71-7.
} 
Mary repeated her "fiat" from the Annunciation, uniting with the destruction of her Son. All this is confirmed by the fact that Mary left a lasting mark on the work of Christ's redemption, cooperating with him actively and not just passively. ${ }^{34}$ At Calvary, Mary united herself completely in a "maternal spirit" with the sacrifice of her Son, "lovingly consenting" to the sacrificial immolation of the Victim to whom she had given birth; whom she also gave to the Eternal Father, though suffering with her Son as much as only a mother can co-suffer. ${ }^{35}$

Bearing in mind the above statements, it is possible to emphasize Mary's special participation in the priesthood of Christ and conclude that Mary under the Cross imprinted a specific, fully maternal mark on the eternal Sacrifice of Christ. When considering the issue of the participation of the faithful in the Holy Mass, it must be stated that the Eucharistic Sacrifice as such, wherever and whenever it is celebrated, bears the indelible Marian mark: not only is it the salvific sacrifice of Christ, but it also makes present forever the sacrifice of the Mother of God, who the faithful, not without reason, led by some bishops and cardinals, call co-redeemer, asking the popes to proclaim the fifth Marian dogma. ${ }^{36}$

When sharing the teaching of the Second Vatican Council on the titles of Mary, one should give her a role in understanding the acclamation after the transubstantiation at each Mass with the words: "We proclaim your death, Lord Jesus [...]," or other, in essence, identical words. The point is to emphasize that the Blessed Virgin teaches us that the Eucharistic proclamation of the Lord's death cannot be something purely formal, that the Crucified "left room in his suffering: for an active 'Yes' on the part of Mary-JohnPeter - and all on behalf of whom they stand." ${ }^{, 37}$

It is worth mentioning the place that St. Faustina Kowalska occupied in the redemptive suffering and sacrifice of Jesus on the cross. In the experience of

\footnotetext{
${ }^{34}$ Cf. Lucjan Balter, "A pod krzyżem stała," in Communio 4, no. 1 (1984): 29-49.

${ }^{35}$ John Paul II, Encyclical Redemptoris Mater, 18; cf. Andrzej L. Krupa, "Maryja w Bożym planie zbawienia," Roczniki Teologiczno Kanoniczne 15, f. 2(1968): 145-9.

${ }^{36}$ Cf. Balter, „A pod krzyżem stała,” 48. It is worth noting that in Lumen Gentium, 62, Mary is called Mediatrix, but not Mediatrix of All Graces. In this document we read: "By her maternal charity, she cares for the brethren of her Son, who still journey on earth surrounded by dangers and cultics, until they are led into the happiness of their true home. Therefore the Blessed Virgin is invoked by the Church under the titles of Advocate, Auxiliatrix, Adjutrix, and Mediatrix. This, however, is to be so understood that it neither takes away from nor adds anything to the dignity and efficaciousness of Christ the one Mediator." A conservative stance towards the mentioned postulates is taken by the Polish Mariologist, Fr. Celestyn Napiórkowski OFMConv, "Współczesne tendencje w mariologii dogmatycznej," Studia Theologica Varsaviensia 27, no. 2(1989): 215-31.

${ }^{37}$ Balthasar, von, "Od Ostatniej Wieczerzy," 188.
} 
one of the Holy Weeks of the Apostle of Divine Mercy, we notice tangible manifestations of mystical death. St. Faustina writes: "Throughout all this time I had been in a sort of swoon. [...] I was dying with him, and yet I could not die. [...] In the course of this suffering, my love grew immeasurably. The world still has no idea of all that Jesus suffered. I accompanied Him to the Garden of Gethsemane; I stayed with him in the prison; I went with Him before the judges; underwent with Him each of the tortures. [...] Friday. In the morning, I at once felt the torture of His five wounds in my body. This suffering continued until three o'clock. Although there is no outward sign of it, the torture is no less painful." $" 38$

The example of the Apostle of Divine Mercy confirms our conviction that the Eucharist allows us to grow up to the point of mystical identification with the sacrifice of Christ, which not only affects its celebration, but also encompasses all moments of human life, is open to others waiting for our support and transforms the earthly reality. The words of the Fourth Eucharistic Prayer of the Mass say it aptly: "We offer you his Body and Blood, the sacrifice acceptable to you which brings salvation to the whole world."

It follows from the above reasoning that the Eucharistic sacrifice, viewed from the perspective of mercy, testifies that it is, in fact, as any sacrifice is, self-communication: "our sacrifice is self-communication to other people and to God, to God through other people. God's self-communication is fulfilled in this self-communication of man Jesus to his brothers: the self-communication of Jesus to people is synonymous with his sacrifice to God." ${ }^{39}$

\section{EUCHARISTIC SACRIFICE AS THE "PLEDGE OF FUTURE GLORY"}

In the exhortation of St. John Paul II Ecclesia in Europa we read that "the Eucharist is a 'taste of eternity within time,' it is God's presence and our communion with that presence. [...] It opens us to the future of God; as communion with Christ, with his body and blood, it is a sharing in God's own eternal life." ${ }^{40}$ We know that Jesus Christ is constantly, in many ways present in his Church. The most important, however, is the personal encounter with

\footnotetext{
${ }^{38}$ St. Faustina Kowalska, Diary. Divine Mercy in My Soul, 3rd ed. (Marian Press, February 15, 2005), no. 1054-1055.

${ }^{39}$ Bernard Sesboüé, Jezus Chrystus jedyny Pośrednik. Rzecz o odkupieniu i zbawieniu, vol. 2 (Poznań: W Drodze, 2016), 291.

${ }^{40}$ John Paul II, Post-Synodal Exhortation Ecclesia in Europa, 75.
} 
Christ at the time of our death. This moment of death, understood as the beginning of a new, eternal life-we all expect.

In order to remain faithful to the subject of the article, it should be clearly stated that primarily the Eucharist is the most trusting expectation for the second coming of Christ, both at the time of our death and at the end of the world. Its eschatic dimension is clearly articulated by the words of acclamation after the consecration: "We proclaim your death, Lord Jesus, we profess your resurrection, until you come again." Here, the words of St Paul come to lips: "For me, living is Christ and dying is gain" (Phil 1:21). Thanks to the Eucharistic presence of Christ's only sacrifice under the species of bread and wine, eternal life becomes our share even now, in this mortal life. By accepting Christ into our hearts in the holy communion, we are already in a state of heaven and we are transforming this world into the reality of God's Kingdom, converting those who have not yet believed.

Recalling once again St. Faustina Kowalska, it is worth referring to her stay in hospital in Krakow, where there was no priest for 13 days. And thenresponding to the thirst of St. Faustina's heart_-an angel brought her the Holy Communion. She wrote then: "At the moment I receive God, all my being is steeped in Him" (Diary, no. 1814) and added: "After Holy Communion. I felt the beating of the Heart of Jesus in my own heart" (Diary, no. 1821). ${ }^{41}$

No wonder that when the dying sister Faustina was last visited by her spiritual director and confessor, blessed Fr. Michał Sopoćko, she seemed to be a heavenly being to him. Blessed Fr. Michał Sopoćko, "then had no doubt that what was written in her Diary about the Holy Communion given in hospital by an angel, corresponds to reality." 42 Undoubtedly, it was a wonderful testimony to the experience of heaven, and thus the mystery of communion of saints and eternal life.

Referring to the participation of the faithful in the Holy Sacrifice of Christ, it should be emphasized again that St. Faustina realized in a unique way the call to experience a mystical death with him and in him. The indescribable sufferings and sorrows of St. Faustina during her stay in hospital in Krakow

\footnotetext{
${ }^{41}$ One can mention here the importance of spiritual communion in the life of a Christian. It takes place in various life situations, when it is not possible to receive Eucharistic communion. But the most important moment is the time of death. We must be aware that in the absence of a priest, at this most decisive moment in life, man can receive spiritual communion and we must help him to experience this moment.

${ }^{42}$ Andrzej Witko, Boża tajemnica miłosierdzia. Święta Faustyna i Nabożeństwo do Miłosierdzia Bożego (Kraków: Wydawnictwo „M”, 2002) , 71; cf. Michał Sopoćko, Mitosierdzie Boga w dziełach Jego, t. 3 (Rzym - Paryż - Londyn, 1962).
} 
bear witness to this. The state of mind of the Apostle of Divine Mercy is revealed by the last words of her Diary, when St. Faustina fervently asks: "Jesus, transform me into another host! I want to be a living host for You. You are a great and all-powerful Lord; You can grant me this favour." And the Lord answered me, You are a living host, pleasing to the Heavenly Father. But reflect: What is a host? A sacrifice. And so ... ? (Diary, no. 1826).

Saying goodbye to the world, St. Faustina wrote: "Today, the Majesty of God is surrounding me. There is no way that I can help myself to prepare better. I am thoroughly enwrapped in God. My soul is being inflamed by His love. I only know that I love and am loved. That is enough for me. I am trying my best to be faithful throughout the day to the holy Spirit and to fulfil His demands. I am trying my best for interior silence in order to be able to hear His voice ..." (Diary, no. 1826). Similar thoughts accompanied the young Blessed Karl Acutis, who, leaving this world, treated the Eucharist as a way to heaven. ${ }^{43}$

In the post-synodal apostolic exhortation of Benedict XVI Sacramentum caritatis we read: "A rediscovery of the eschatological dimension inherent in the Eucharist, celebrated and adored, will help sustain us on our journey and comfort us in the hope of glory (cf. Rom 5:2; Tit 2:13)." ${ }^{44}$ Therefore, it should be noted that, thanks the Eucharist, God, through Christ in the Holy Spirit, has chosen to be the God of the eschatological future of man, showing him the Christian way of life and death. What is to come is already taking place in the dying and resurrection of the Incarnate God, present in the Eucharistic sacrifice. Thus, the Eucharist makes it possible to understand that the passage through death is the accomplishment of the incorporation in the rise of Jesus to a new life in heaven. ${ }^{45}$

In conclusion, it should be stressed that after the introduction of the world into the third millennium of Christianity, John Paul II stated that the

\footnotetext{
${ }^{43}$ Cf. Venerable Carlo Acutis and his love for the Eucharist, https://www.catholicnewsagency.com/ news/venerable-carlo-acutis-and-his-love-for-the-eucharist-59738 (13 XI 2020); Nicola Gori, Eucharystia. Moja autostrada do nieba. Historia Carla Acutisa (Kraków: wyd. eSPe, 2020).

${ }^{44}$ Benedict XVI, Post-Synodal Apostolic Exhortation Sacramentum caritatis, 32.

${ }^{45}$ William J. Hill, "Eucharystia jako obecność eschatologiczna," trans. Julian Warzecha, in Communio. Międzynarodowy Przegląd Teologiczny, vol. 1: Eucharystia, ed. Paweł Góralczyk (Poznań-Warszawa: Pallottinum, 1986), 327-39.
} 
Church does not need to search for a new programme. ${ }^{46} \mathrm{He}$ was convinced that this programme is contained in the Gospel and the living tradition of the Church, and that "the implementation of this programme of a renewed impetus in Christian living passes through the Eucharist." ${ }^{\text {" }}$ The content of this article, coinciding with the slogan of the next pastoral year for the Church in Poland, fully shares the quoted words of the Polish Pope. The three-year pastoral programme, referring to the apostolic exhortation of Benedict XVI Sacramentum caritatis, is devoted to the Eucharist as a confessed and celebrated mystery. It is to be hoped that bending over to the Eucharistic sacrifice will deepen the celebration of the Blessed Sacrament with a closer relationship of the faithful with Eucharistic Jesus.

\section{BIBLIOGRAPHY}

Balter, Lucjan. „A pod krzyżem stała.” Communio 4, no. 1 (1984): 29-49.

Balthasar, Hans Urs von. "Od Ostatniej Wieczerzy do ofiary Kościoła.” In Communio. Międzynarodowy Przeglad Teologiczny, vol. 1: Eucharystia, edited by Paweł Góralczyk, 175-88. Poznań-Warszawa: Pallottinum, 1986.

Benedict XVI. Catechesis from January 11, 2012, http:/www.vatican.va/content/benedict-xvi/en/ audiences/2012/documents/hf_ben-Xvi_aud_20120111.html

Benedict XVI. Post-Synodal Apostolic Exhortation Sacramentum caritatis. On the Eucharist as the Source and Summit of the Church's Life and Mission. Rome, February 22, 2007. http://www.vatican.va/content/benedict-xvi/en/apost_exhortations/documents/hf_ben-xvi_exh_ 20070222_sacramentum-caritatis.htm.

Collins, John C. "The Eucharist as Christian Sacrifice. How Patristic Authors Can Help us Read the Bible." Westminster Theological Journal 66, no. 1 (2004): 1-23.

Dulles, Avery, S.J. "The Eucharist and the Mystery of the Trinity." In Rediscovering the Eucharist. Ecumenical Conversations, edited by Roch A. Kereszty, 226-39. Mahwah, N.J.: Paulist Press, 2003.

Francis Pope. Post-Synodal Apostolic Exhortation Querida Amazonia. Rome, February 2, 2020. http://www.vatican.va/content/francesco/en/apost_exhortations/documents/papa-francesco_ esortazione-ap_20200202_querida-amazonia.html.

Gori, Nicola. Eucharystia. Moja autostrada do nieba. Historia Carla Acutisa. Translated by Joanna Curyło. Kraków: Wydawnictwo eSPe, 2020.

Hill, William J. "Eucharystia jako obecność eschatologiczna." Translated by Julian Warzecha. Communio. Międzynarodowy Przegląd Teologiczny, vol. 1: Eucharystia, edited by Góralczyk Paweł, 327-39. Poznań - Warszawa: Pallottinum, 1986.

Jan Paweł II. Komentarz do Ksiag Nowego Testamentu. Kraków: Wydawnictwo M, 2012.

\footnotetext{
${ }^{46}$ Cf. John Paul II, Encyclical Letter Ecclesia de Eucharistia, 60.

${ }^{47}$ Ibidem.
} 
John Paul II. Catechesis at the general audience of October 11, 2000, http://www.vatican.va/content/ john-paul-ii/en/audiences/2000/documents/hf jp-ii aud 20001011. html

John Paul II. Encyclical Letter Ecclesia de Eucharistia. Rome, April 17, 2003. http:// www.vatican.va/content/john-paul-ii/en/encyclicals/documents/hf_jp-ii_enc_20030417_ecclde-euch.html.

John Paul II. Encyclical Redemptoris Mater. On the Blessed Virgin Mary in the Life of the Pilgrim Church. Rome, March 25, 1987. http:/www.vatican.va/content/john-paul-ii/en/ encyclicals/documents/hf_jp-ii_enc_25031987_redemptoris-mater.html.

John Paul II. Letter Dominicae cenae. On the Mystery and Worship of the Eucharist. Vatican, February 24, 1980. http://www.vatican.va/content/john-paul-ii/en/letters/1980/documents/hf jp-ii_let_19800224_dominicae-cenae.html.

John Paul II. Post-Synodal Apostolic Exhortation Ecclesia in Europa. On Jesus Christ Alive in his Church the Source of Hope for Europe. Rome, June 28, 2003. http://www.vatican.va/ content/john-paul-ii/en/apost_exhortations/documents/hf_jp-ii_exh_20030628_ecclesia-ineuropa.html.

Jan Paweł II. Dar i tajemnica. Kraków: Wydawnictwo św. Stanisława BM, 1996.

Joy, John P. "Ratzinger and Aquinas on the Dating of the Last Supper. In Defense of the Synoptic Chronology." New Blackfriars 94, no. 1051 (2013): 324-39.

Kereszty, Roch A. "The Eucharist of the Church and the One Self-Offering of Christ." In Rediscovering the Eucharist. Ecumenical Conversations, edited by Roch A. Kereszty, 240-60. Mahwah, N.J.: Paulist Press, 2003.

Kowalska Faustina St. Diary. Divine Mercy in My Soul. 3rd ed. Marian Press. February 15, 2005.

Krupa, Andrzej L. "Maryja w Bożym planie zbawienia.” Roczniki Teologiczno-Kanoniczne 15, f. 2 (1968): 117-55.

Napiórkowski, Celestyn Stanisław. "Współczesne tendencje w mariologii dogmatycznej." Studia Theologica Varsaviensia 27, no. 2 (1989): 215-31.

Ozorowski, Edward. "Ofiara jako 'primum principium' Eucharystii." Rocznik Teologii Katolickiej 5 (2006): 9-21.

Paul VI. Apostolic Letter Solemni hac liturgia (Credo of the People of God), June 30, 1968. http:// www.vatican.va/content/paul-vi/en/motu_proprio/documents/hf_p-vi_motu-proprio_19680630 credo.html.

Pius XII. Encyclical Mediator Dei et hominum. Castel Gandolfo, November 20, 1947. http:// www.vatican.va/content/pius-xii/en/encyclicals/documents/hf_p-xii_enc 20111947 mediatordei.html.

Ratzinger, Joseph. Eucharystia. Bóg blisko nas. Kraków: Wydawnictwo M.

Ratzinger, Joseph. "Ostatnia Wieczerza a Eucharystia Kościoła.” In Communio: Międzynarodowy Przegląd Teologiczny. Świeccy w Kościele, edited by Lucjan Balter, Kazimierz Czulak, Paweł Góralczyk, and Stanisław Stancel, 162-74. Poznań-Warszawa: Pallottinum, 1987.

Sacred Congregation of Rites. Eucharisticum Mysterium - Instruction on Eucharistic Worship. Rome, May 25, 1967. https://adoremus.org/1967/05/eucharisticum-mysterium/.

Sacred Congregation of the Doctrine of the Faith. Sacerdotium Ministeriale. Letter to Bishops of the Catholic Church on Certain Questions Concerning the Minister of the Eucharist. Rome, August 6, 1983. AAS 75 (1983): 1001-1009. 
Sesboüé, Bernard. Jezus Chrystus jedyny Pośrednik. Rzecz o odkupieniu i zbawieniu, vol. 2. Poznań: W Drodze, 2016.

Siebel, Wigand. Freihait und Herrschaftsstruktur in die Kirche. Eine soziologische. Studie. Berlin: Morus-Verlag, 1971.

Siudy, Teofil. "Wiara - jakby klucz do prawdy o Maryi." In Matka Odkupiciela. Text and comments, edited by Stanisław Celestyn Napiórkowski, 71-7. Lublin: Redakcja Wydawnictw KUL, 1993.

Sopoćko, Michał. Miłosierdzie Boga $w$ dziełach Jego, t. 3. Rzym-Paryż-Londyn: Kuria Metropolitalna Białostocka, 1962.

The Council of Trent, Session 22. On the Sacrifice of the Mass. Accessed December 12, 2020. http://www.thecounciloftrent.com/ch22.htm.

Tripp, David H. "Protestantism and the Eucharist." In The Study of Liturgy, edited by Cheslyn Jones, Geoffrey Wainwright, Edward Yarnold, and Paul Bradshaw, 295-309. London: Oxford University Press, 1992.

Vaticanum II. Dogmatic Constitution on the Church Lumen gentium solemnly promulgated by his holiness pope Paul VI, November 21, 1964. http://www.vatican.va/archive/hist_councils/ ii_vatican_council/documents/vat-ii_const_19641121_lumen-gentium_en.htm

Vaticanum II. Decree on the Ministry and Life of Priests Presbyterorum ordinis Promulgated by His Holiness Pope Paul VI, December 7, 1965. http://www.va/archive/hist_councils/ii_vatican council/documents/vat-ii_decree_19651207_presbyterorum-ordinis_en.html.

Venerable Carlo Acutis and his love for the Eucharist. Accessed November 13, 2020. https:// www.catholicnewsagency.com/news/venerable-carlo-acutis-and-his-love-for-the-eucharist-59738.

Warchoł, Paweł. Krew i Woda, dar Miłości miłosiernej. Warszawa: Wydawnictwo Sióstr Loretanek, 2015.

Watts, Alan M. "Sacrament and Sacrifice. Attending to Some Neglected Biblical Threads." Toronto Journal of Theology 24, no. 1 (Suppl.) (2008): 143-52.

Witko, Andrzej. Boża tajemnica miłosierdzia. Święta Faustyna i Nabożeństwo do Miłosierdzia Bożego. Kraków: Wydawnictwo „M”, 2002.

\section{WSPÓŁUCZESTNICTWO W EUCHARYSTYCZNEJ OFIERZE CHRYSTUSA}

$$
\text { Streszczenie }
$$

Pozostając w nurcie programu duszpasterskiego Kościoła w Polsce, realizowanego pod hasłem „Zgromadzeni na Świętej Wieczerzy”, treść artykułu koncentruje się na analizie i syntezie dokumentów Urzędu Nauczycielskiego Kościoła oraz publikacji teologicznych o Ofierze eucharystycznej. Artykuł omawia najpierw eucharystyczne uobecnienie Ofiary Krzyżowej jako daru Chrystusa uwielbionego, aby następnie zwrócić uwagę na potrzebę czynnego udziału wiernych w eucharystycznym uobecnieniu wydarzenia Kalwarii. Podkreśla się też kontekst miłosierdzia Bożego w Ofierze eucharystycznej. Zwieńczeniem artykułu jest interpretacja eschatycznego wymiaru Eucharystii, potwierdzona świadectwem życia chrześcijan, włączających się w ofiarę Chrystusa oraz w Jego śmierć i zmartwychwstanie, które owocują doskonałą radością zbawionych w niebie.

Słowa kluczowe: Eucharystia jako ofiara doskonałej czci; uobecnienie jedynej Ofiary Chrystusa; eschatyczny wymiar Eucharystii. 